\title{
Existing Improvements in Simulation of Fire-Wind Interaction and Its Effects on Structures
}

\author{
Maryam Ghodrat ${ }^{1, * \mathbb{D}}$, Farshad Shakeriaski ${ }^{1} \mathbb{D}$, David James Nelson ${ }^{2} \mathbb{D}$ and Albert Simeoni ${ }^{3}$ \\ 1 School of Engineering and Information Technology, University of New South Wales Canberra, \\ Canberra, ACT 2610, Australia; f.shakeriaski@gmail.com \\ 2 School of Aerospace, Mechanical and Mechatronic Engineering, The University of Sydney, \\ Camperdown, NSW 2006, Australia; dne19041@uni.sydney.edu.au \\ 3 Department of Fire Protection Engineering, Worcester Polytechnic Institute, Worcester, MA 01605, USA; \\ asimeoni@wpi.edu \\ * Correspondence: m.ghodrat@adfa.edu.au
}

Citation: Ghodrat, M.; Shakeriaski, F.; Nelson, D.J.; Simeoni, A. Existing Improvements in Simulation of Fire-Wind Interaction and Its Effects on Structures. Fire 2021, 4, 27. https://doi.org/10.3390/ fire4020027

Academic Editor: Chad M. Hoffman

Received: 22 April 2021

Accepted: 5 May 2021

Published: 10 May 2021

Publisher's Note: MDPI stays neutral with regard to jurisdictional claims in published maps and institutional affiliations.

Copyright: (c) 2021 by the authors. Licensee MDPI, Basel, Switzerland. This article is an open access article distributed under the terms and conditions of the Creative Commons Attribution (CC BY) license (https:/ / creativecommons.org/licenses/by/ $4.0 /)$.

\begin{abstract}
This work provides a detailed overview of existing investigations into the fire-wind interaction phenomena. Specifically, it considers: the fanning effect of wind, wind direction and slope angle, and the impact of wind on fire modelling, and the relevant analysis (numerical and experimental) techniques are evaluated. Recently, the impact of fire on buildings has been widely analysed. Most studies paid attention to fire damage evaluation of structures as well as structure fire safety engineering, while the disturbance interactions that influence structures have been neglected in prior studies and must be analysed in greater detail. In this review article, evidence regarding the fire-wind interaction is discussed. The effect of a fire transitioning from a wildfire to a wildlandurban interface (WUI) is also investigated, with a focus on the impact of the resulting fire-wind phenomenon on high- and low-rise buildings.
\end{abstract}

Keywords: fire propagation; fire-wind interaction; low-rise building; high-rise buildings; WUI

\section{Introduction}

Bush and grassland fires are the most frequent type of fires in Australia. These fires account for over $30 \%$ of total annual fire incidents [1] and are the fourth most hazardous natural disaster (after heat waves, tropical cyclones and floods) in Australia [2]. In the most recent bushfire of 2019-2020 that swept almost the entire country, over $21 \%$ of Australian forests and bushland (excluding Tasmania) were affected [3]. Fire destroyed more than 2000 buildings (a conservative estimate), 34 people lost their lives and nearly 3 billion animals were killed or displaced [4]. The recovery cost is estimated to be over 100 billion Australian dollars [5]. This clearly necessitates broad and systematic investigation into the causes of the incident, prediction methods and the development of new technologies to characterise and control future wildfires. The interaction of fire and wind is of great importance in fire science, as fire has been shown to strongly distort downstream airflow. Extensive surveys have been conducted within the field to explore the various behaviours of wildfires in both still air and windy conditions [6,7]. Several studies have been devoted to the burning behaviour of fires in windy conditions and the effects of wind on flame features [8-11], burning rate [12-15], flame height and tilt angle $[6,16]$. Further existing studies have been conducted on the effects of ambient wind velocity and heading on a fire [17-20]. The wind can significantly affect the design of fire safety procedures for structures, and this has not been addressed in previous reviews. To address this, the present review elaborates upon existing investigations of the wind-fire interaction phenomenon. The effect of wind-fire enhancement on low- and high-rise buildings is broadly discussed. This review also presents a discussion on the effect of wind as it transitions from a wildfire regime to a WUI regime and its effect on buildings. The associated techniques, which 
include analytical simulations and numerical and experimental analyses, are also addressed in detail.

\section{Fire-Wind Interaction}

In contrast with fires in still air that are driven primarily by the buoyancy force, the behaviour of fires subject to wind is a much more complicated phenomenon. Wind has a significant impact on fire behaviour because of the fanning effect. A diagram that shows the different interactions between wind and fire is shown in Figure 1.

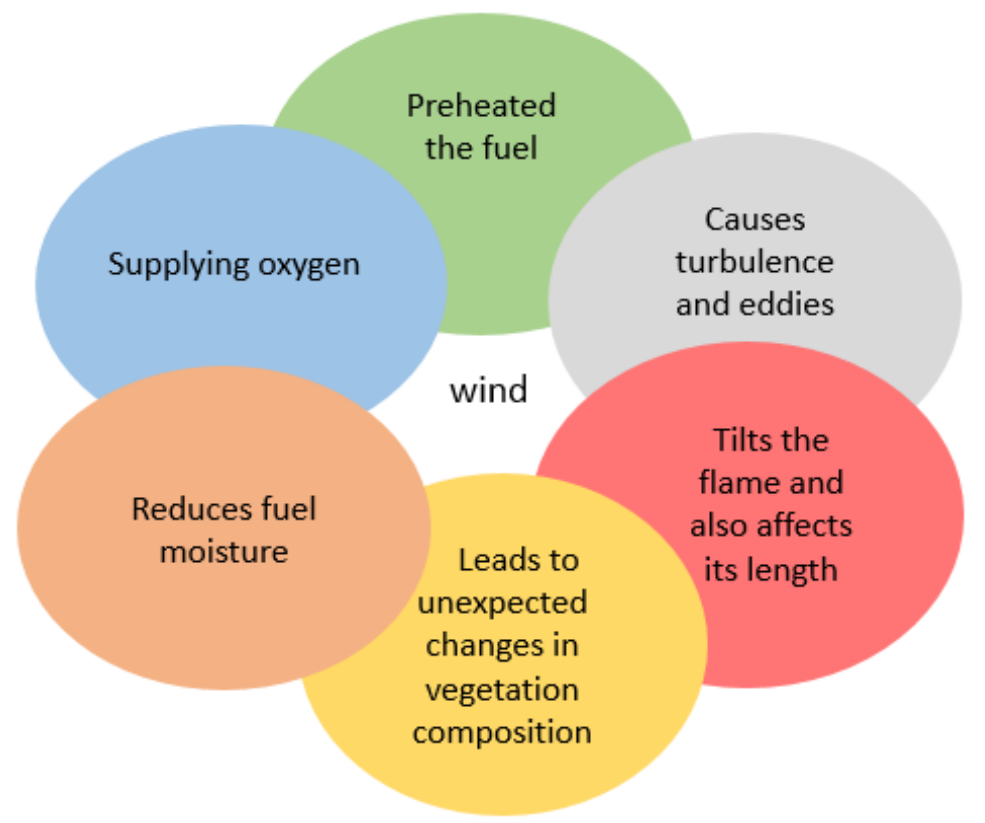

Figure 1. Interaction between wind and fire.

\subsection{Fanning Effects of Wind}

Wind can change in strength and direction throughout the day. This change might be very abrupt. In the case of planned burns, this can cause a controlled fire to suddenly become uncontrolled without adequate alert mechanisms. The fanning effect increases the source of oxygen, leading to more intense fires. Wind also reduces the humidity of the surface fuel, resulting in drier fuel beds and further increasing the flame intensity. The resulting air pressure will force firebrands, sparks and flames to move and reach a new source of fuel in the surrounding environment. By moving the flames closer to a new fuel bed, the wind causes faster preheating of the fuel due to increased radiant thermal energy. Much of the fuel is accessible for combustion, as it is drier and therefore can obtain ignition temperatures much faster. The fire increases radiation in some conditions leading to burning embers and firebrands. One of the well-studied mechanisms by which forest wind-fire disturbances interact is that wind damage increases the amount of flammable fuels-intensifying the fire-resulting in unanticipated changes in vegetation composition. Nonetheless, wind disturbance might buffer the impacts of fire by mechanisms such as discrete fuel beds $[15,21]$.

\subsection{Effects of Wind Direction and Slope Angle on Fire}

Topographic slope and wind direction are significant factors that determine the direction and spread rate of wildfires. Most analyses of the impacts of slope angle or wind on fire spread rate have been conducted experimentally. Instances are analysed by Fang [22], Sheshukov [23] and Van Wanger [24]. Nelson [19] applied a trigonometric technique to mix the ambient wind speed with the upslope part of a fire's buoyant speed to define an "effective wind speed" that characterised the fire-wind system. The simulation was 
examined with information from empirical results by Weise [25] focusing on the effect of slope angle and wind velocity on fire spread. It was shown that the effective wind velocity correlates with Weise's tests and produces accurate predictions of the fire spread rate when slope and wind were considered. Linn et al. [26] applied the term "point-functional models" to describe simulations employing terrain and wind data at a single point in space to determine the direction and fire spread rate in the experimental domain. The authors presented some instances of conditions in which local data on terrain and wind factors should provide decent fire spread conditions and estimated where the approach would likely not work.

Therefore, while slope and wind correction techniques can improve the predictive ability of such models, their results do not accurately reproduce many of the effects seen experimentally [27]. Weise and Biging [28] presented a comparison of some point-functional fire spread simulations combining slope and wind impacts and compared their estimations with empirical information. Sharples [27] produced a range of techniques that corrected the predicted fire spread rate according to topographic slope and wind. The techniques were derived from experimental results, geometric reasoning or a combination of both According to their results, vector techniques presented more realistic outcomes than scalar techniques, likely due to the insensitivity of the scalar techniques to the directional effects of slope and wind. The vector techniques do consider the alignment of slope and wind impacts. Sharples et al. [29] investigated terrain-revised winds by applying joint probability distributions resulting from wind velocity and direction information gathered in rugged terrain to the southwest and west of the Australian Capital Territory. The authors discussed two landform features: a moderately steep valley and a steep slope. Sharples also [30] showed the results of some primary combustion tunnel tests, illustrating the presence of the fire channeling event. The slope was covered by fuel contained in a $1 \mathrm{~m} \times 2 \mathrm{~m}$ steel wire mesh. Figure 2 demonstrates the approximate point of ignition and the cross-section of the empirical ridge shape.

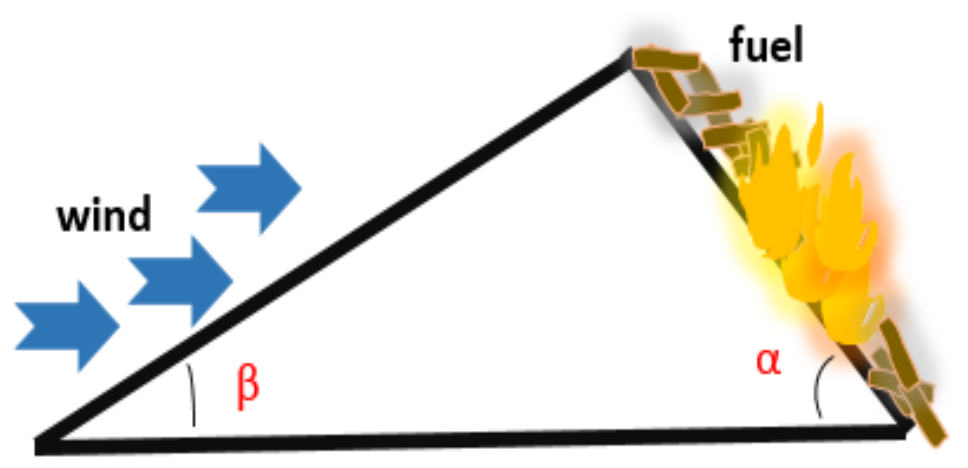

Figure 2. Point of ignition and the cross-section of the empirical ridge shape.

In these tests, the slope angles $\beta$ and $\alpha$ were $20^{\circ}$ and $35^{\circ}$, and the tests were conducted in the presence of a $4 \mathrm{~m} \mathrm{~s}^{-1}\left(\sim 15 \mathrm{~km} \mathrm{~h}^{-1}\right)$ wind. The resulting fire extension across the slope was different in the presence of the $4 \mathrm{~m} \mathrm{~s}^{-1}$ wind in comparison to the no wind instances. Figure $3 \mathrm{a}, \mathrm{b}$ show the difference in lateral extension features for the no-wind and wind cases. Figure $3 c, d$ illustrate that analogous unusual extension happened as the ignition was made on the centre and the left side of the slope. Based on this observation, central ignition resulted in fast lateral extension occurring in both directions along the slope top. 


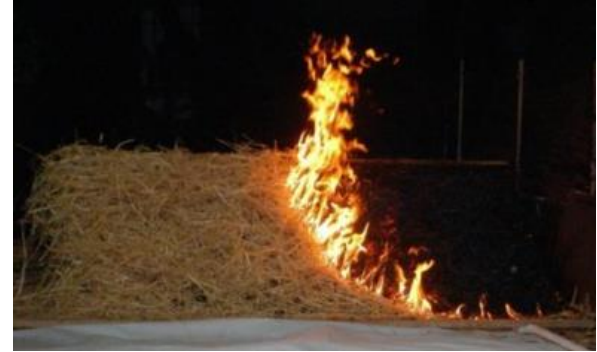

(a)

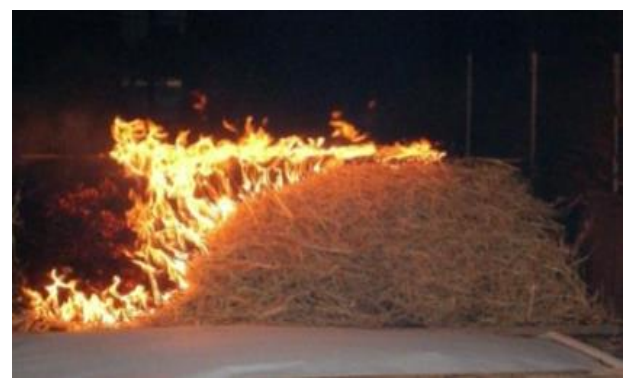

(c)

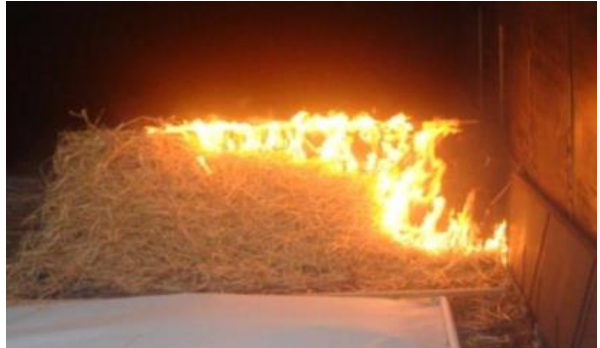

(b)

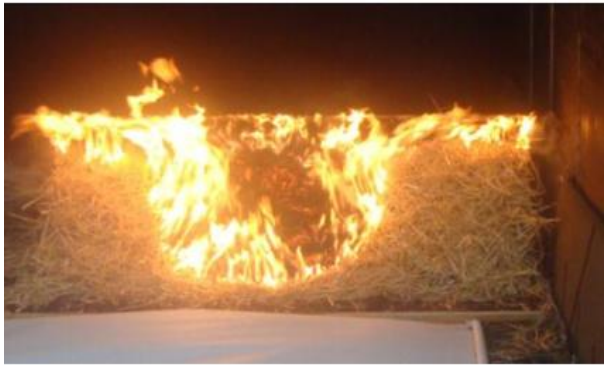

(d)

Figure 3. Empirical fires which burn across the lee slope. (a) No wind, right-side ignition; (b) $4 \mathrm{~m} \mathrm{~s}^{-1}$ wind, right side ignition; (c) $4 \mathrm{~m} \mathrm{~s}^{-1}$ wind, left side ignition; (d) $4 \mathrm{~m} \mathrm{~s}^{-1}$ wind, central ignition [30].

\subsection{Fire Modelling and Wind Interaction}

Wind is one of the main controlling parameters that specifies the direction, spread rate and configuration of a fire. Each side of the fire is expressed in terms of rear, flank and head. The head is the fastest spreading section of a fire. It typically shares the same heading as the midflame velocity, and it will always be the upslope face of a fire. Opposite the head of the fire is the rear. The left and right flanks are the sides of the fire perpendicular to the head and rear. Figure $4 \mathrm{~b}$ shows the arrangement of head, rear and flanks.

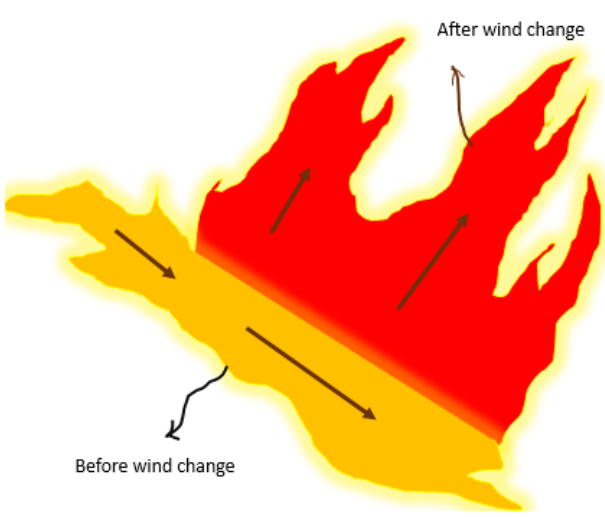

(a)

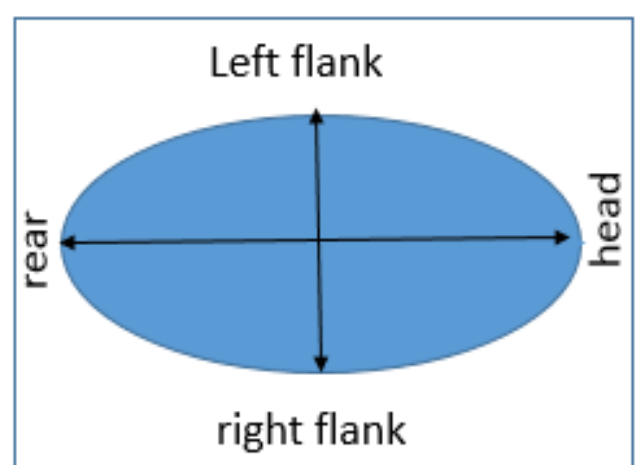

(b)

Figure 4. (a) A flank fire produced by alteration in the direction of wind. (b) Different sides of the fire in terms of head, rear and flank.

The wind driving a fire can change at any time, and a rotation in wind heading of $90^{\circ}$ can rotate the fire itself such that the flank is now the head, resulting in a new fire front that is much larger and harder to control compared to the initial narrow fire. This presents a grave hazard to personnel attempting to suppress the fire. Figure 4a shows the fire spread pattern that can result from a variation of this form. Zheng et al. [31] analysed the impacts of wind axis on the vertical and lateral flame spread velocity with no fire barrier designs while being forced by a wind velocity of $2.5 \mathrm{~m} / \mathrm{s}$. The results of their empirical investigations 
show that as the angle between the wall and the wind axis increases from $0^{\circ}$ to $60^{\circ}$, the mean peak vertical flame spread rate declines whereas the mean peak lateral flame spread rate goes up. The outcomes demonstrate that the maximum lateral and vertical flame spread rates show regular variations at single wind directions. Wind axis distributions were simulated by Quill et al. [32]. They used a diagnostic simulation linked to a fire spread estimation. The analysis aimed at understanding these limitations in a probabilistic context, by comparing individual deterministic estimations to observed distributions of wind direction. The comparisons detailed in this analysis show the potential for the presented model to estimate multi-modal wind direction distributions representing complicated wind behaviours, which include re-circulation regions on leeward slopes. The expression of the wind as a boundary condition in modelling is an accomplishment of the meso-scale atmospheric phenomena via an Atmospheric Boundary Layer simulation in CFD [33]. This implementation typically needs to have three terms specified, including a vertical profile for average speed, the turbulence features and the upstream aerodynamic roughness length. The aerodynamic roughness length (which is typically introduced as the height where the wind speed is equal to zero) is calculated by applying Davenport categorisation [34], and this term will specify the speed profile and turbulence factors of the wind flow. The aerodynamic roughness length therefore fully specifies this model.

\section{Fire-Wind Interaction and Structures}

\subsection{Effect of Wind Transition from Wildland to WUI}

In the last few years, wildland-urban interface fires have attracted much attention. Prolonged drought situations mixed with dry, hot winds blowing over mountains and across plains create climates vulnerable to wind and fire. Greater wind velocities are also related to fast traveling wildfire. Depending on the exposure conditions, buildings might ignite when a wildland fire spreads to a WUI community. The number of people living in communities within WUIs is increasing due to population growth and increased expansion of housing development into wildland regions. Accurately estimating the ignition capability of buildings and mitigation paths to decrease or avoid their ignition is important to decreasing losses in WUI areas. Wildland-urban interface fires are a serious threat to communities worldwide. Some examples include Florida in 1998, Greece in 2007, Australia in 2009 and many others. These can result in destructive consequences in terms of economic and human factors [35].

As discussed previously, the ambient wind has a significant effect on the progression of fire fronts and firebrand transfer. San Diego University and NIST are in the initial stages of research on the area measurement of wind in this field. The main objective of their project is to collect useful wind measurements in high-wind conditions and terrain analogous to those seen in WUI communities and perform analysis of the resulting fire phenomena. [35]. In the 1900s, scientists tried to suppress wildfire perfectly. These practices allowed the buildup of near-ground vegetative substance in jungles so that when a fire occurred, it burned with a larger strength than if this substance had been expunged by more frequent, however less intense, fires [36]. These days, the strategy is that fire is a natural event in forests and that low-intensity, periodic fires contribute to maintaining a forest floor clear of vegetative debris, which can accelerate typically low-intensity fires. It is believed that forests that have been cleared by tiny fires are healthier and can resist the adverse impacts of large wildfires. In both WUI and wildland fires, spot fires which are ignited by brands are a basic fire-spread system. In wildland-urban interface fires, firebrands are able to ignite houses, generating a severe structural fire and also drive further brand generation while the surrounding trees stay untouched (the example of this event is the Angora Fire that happened near Lake Tahoe on June 2007) [36,37].

Simulations estimating WUI fires are more complex compared to those of wildland fires due to fuel heterogeneity. In addition, the instruments used to address WUI fires have not been improved in spite of the fact that the risk and cost of such fires have grown substantially. Rehm [36] produced a simple simulation demonstrating the impact 
of grass-fire propagation on the winds produced by a structural fire in a WUI setting. The author considered a topographical wind and an ambient wind which were presumed to be proportional to the slope of the ground. The changes in the fireline spread when different terms are altered, including the location and the number of burning buildings, were analysed in their research work. Rehm [38] also presented a simple mathematical simulation for the estimation of the grass-fire front propagation resulting from an ambient wind and by entrainment winds produced from one or more burning buildings. The transition of fire between the mediums of grass and structure occurs in this simulation either by direct flame impingement of the grass flame on a structure or by embers or brands that can ignite buildings directly or produce grass spot fires that then ignite buildings further ahead of the fire front. The impact of the entrainment winds from burning buildings on the propagation of a grass fire were shown. Their outcomes showed that the fuel mechanism for WUI fires should include both buildings and vegetation, and that the grass fire front progression can change dramatically when large numbers of buildings are ignited. Mahmoud and Chulahwat [39] claimed to find and quantify the impacts of a number of intrinsic parameters relating to the layout and constitution of a built-up community and mitigation parameters to the propagation of fire through the community. These factors can be used to define a community vulnerability. The authors considered intrinsic parameters such as wind direction, community layout, wind velocity and the presence of wildland vegetation near the given community. High velocity winds had a significant effect on ember generation, causing the fire to propagate rapidly. By igniting specified buildings in the community, the wildfire can propagate rapidly. The authors claimed that discontinuities in the layout of these communities reduced the propagation of fire. Reverse engineering was used to specify the boundary restrictions of wildland vegetation that minimised this fire propagation.

Depending on the wind conditions within a wildland-urban interface fire, the community requires a specified level of resilience achieved through the use of techniques and equipment such as the integration of fire-proof substances, automatic sprinkler mechanisms and the clean-up of stray vegetation.

\subsection{Effect of Wind-Fire Interaction on Urban Buildings}

The ignition of exterior and interior structures is a primary concern in WUI fires. Developing the construction and design of buildings to reduce fire-related damages is the key measure to occupiers and property owners in addressing the damaging impacts of bushfires events. This includes standards governing both the design of these buildings and also what actions should be taken in response to a fire. These actions must also be known by residents living in these areas to mitigate the damage to structures in the event of a fire. The modern attitude is that good design, sensible maintenance and careful construction will result in buildings that not only protect the occupants against fires, but also from storms and other natural events. The fire safety community has long identified the requirement of integration and acted accordingly in response to the design procedure of buildings. Moreover, to deliver a quantifiable safety efficiency, the fire safety community has considerably invested in the improvement of physics-based instruments that have been essential to the approval and design of numerous structural features [40-43].

Fires can extend to structures and buildings through openings. The simplified procedure of heat transfer within the heating up time of a substance is shown in Figure 5. Thermal energy is transmitted from the attacking fire to the substance surface by convection and radiation. At the same time, there are thermal energy losses from the surface by convection and radiation to the environment and thermal energy is also diffused throughout the substance. If the total thermal energy transfer from the fire is high enough, the substance surface temperature will be increased to the ignition range [44]. 


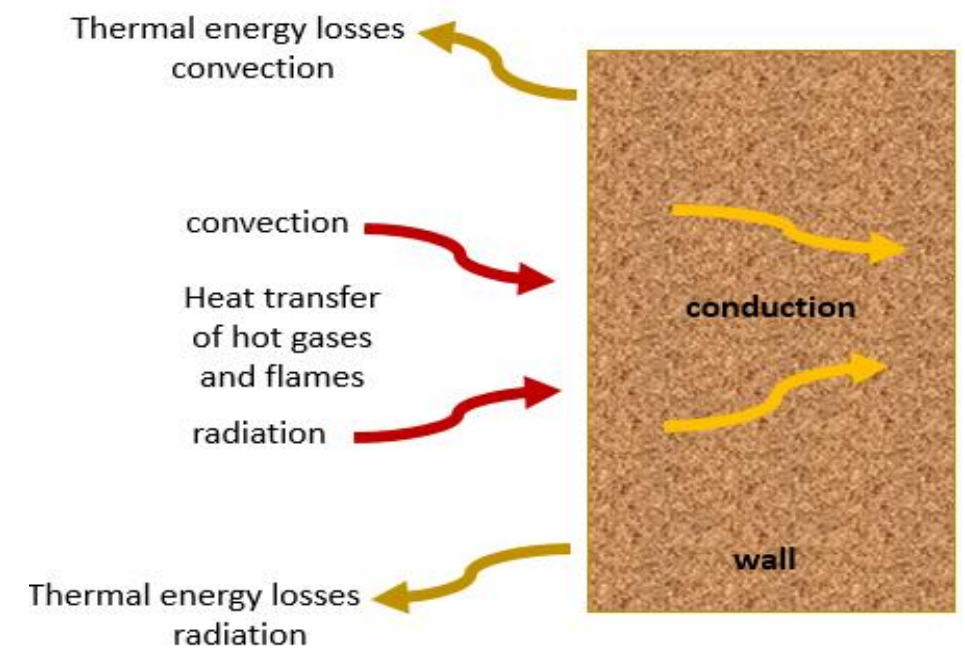

Figure 5. A summary of heat transfer processes in the heating up a wall.

As mentioned in previous sections, wind characteristics play a significant and complicated role on the assessment of fire risks [45-47]. According to results presented by Ramsay et al. [48], wind is the primary mechanism through which fires cause property damage, blowing roofs off and breaking windows. Predictions also tend to underestimate the intensity of winds associated with fire [49].

Fire-wind phenomena can be a devastating force in many cases, including fire inside or around buildings and wildfires close to urban areas. These fires can release large amounts of smoke into an urban region. The Fire Dynamics Simulator uses CFD codes to estimate the heat transfer and smoke spread both within and outside buildings [50,51]. The coupling of computational wind engineering and fire dynamics is introduced by considering the wind speed which is an essential parameter in modelling wildfire propagation.

Numerical analysis performed by He et al. [52] showed that the interaction between bushfire and wind generates a powerful local impact at areas closer to the ground or even at scales equivalent to the sizes of buildings. The buoyancy flux and mixed momentum can significantly distort the velocity profile of the wind such that the velocity of the wind near the ground is increased by over 50 percent at a given distance downstream of a moderate fire front. The wind-fire interaction also generates powerful turbulence and intermittent gusts of up to twice the upstream speed can be seen. Structural standards must therefore consider wind loading in fire-prone areas.

By running extensive wind tunnel experiments, Kramer and Gerhardt [53] investigated the wind flow field and the efficiency of natural ventilation associated with industrial structures. The authors presented the flow field properties on the roof, introducing a reliance on the relative height of the building. They described the pressure profile on industrial roofs [54] and have done more research associated with natural smoke venting efficiency [55]. This analysis was conducted in a boundary layer wind tunnel, and the significance of the width-height ratio of structures on the flow was specified. The strength of the fire is one of the main boundary conditions in the investigation of the impact of fire on buildings. As the results showed, larger roofs and external walls are more affected by firebrands and heat and should therefore be built of substances that mitigate fire spread.

The challenge engineers face in simulating the unpredictable nature and behaviour of wind and fire are presented in research done by Johannson and Ekholm [56]. They asserted that there are various assumptions in fire safety engineering. Based on their results, fire is a complex event and reducing the model with assumptions can lead to significant losses in accuracy. Generally, inaccuracies occur due to inadequate quality control, caused mainly by a lack in funding. Inadequate knowledge regarding fire dynamics is the major problem that should be considered. 
In most cases, the exposure of structural materials to wind and fire results in significant heating of the material, often leading to mechanical failure as the material properties are weakened. This can happen due to various thermal decomposition processes such as ignition and pyrolysis, or mechanical weakening of the part under extreme heat. Analyses of fire behaviours in the compartments of low- and high-rise structures in the presence of wind requires finding efficient techniques to assess smoke control and movement. The major research addressing this field is reviewed in the following sections.

\subsubsection{Fire-Wind Interaction Effects on Low-Rise Building}

The direction and velocity of atmospheric wind are changing continuously. Wind heading can naturally vary by up to $90^{\circ}$ in less than half an hour. If wind blows against a room with an open window, it can lead to an increase in the room's pressure. If the room does not have other windows or openings, the pressure will increase in direct proportion to the wind velocity. After some time, the room pressure will equalise and flow into the room will cease. If the room is open to the outdoors at an opposing wall, the lower ambient pressure on the leeward side of the building will drive airflow through the building towards this opening [57]. Construction practices laid out in standards and building codes [58] present some chances for developing structural resilience in fire-wind events. Ong et al. [59] used CFD tools to investigate a low-rise structure that was immersed in a turbulent boundary layer. Their study was one of the initial endeavours to analyse peak pressure using large eddy simulations in order to present guidelines for the setup of Computational Fluid Dynamics models applied to assess quantities that are fundamental in numerous uses, for instance, in cladding design. Zhang et al. [60] designed an empirical facility to investigate the wind load in a wind tunnel. The facility included a model building and a barrier. The wind impacted the barrier, resulting in recirculation on the leeward side of the model. The tests were performed by locating the model in the wind tunnel centre as shown in Figure 6. The target of these tests was to provide a basic model of the airflow in the recirculation region between the building model and the barrier. The impact of wind on indoor airflow behaviour and smoke movement were modelled using CFD simulations in the work of Šulc et al., Franke et al., Barsim et al. and Assunta et al. [61-65]. This research has resulted in more effective fire action plans in the case of an incident. The authors observed that the vortex strength is related to the recirculating wind velocity and higher wind velocity will lead to a larger interface layer. The results indicated that in a fire event the leeward windows should be closed. The influence of wind on smoke migration inside a room under various headings and velocities was investigated numerically by Dan and Wen-lei [66] in 2011. According to their research, if the wind velocity reaches a critical level, the wind velocity at the inlet of the building depends on the larger of either the smoke entrainment velocity or natural wind velocity. A wind velocity higher than that driven by smoke entrainment also negatively affects the efficiency of smoke control mechanisms. Their results also indicated that further analysis is required to investigate the critical wind velocity at the doorway.

Variation in the ventilation of buildings, including openings such as windows and doors can escalate the fire and lead to fast propagation. This will also increase the gases produced in a fire event $[67,68]$. Kandola [69] found that the impact of wind cannot be neglected because it might impinge on the efficiency of ventilators or cause a reversed stream in vents. Morgan and Marchant [70] identified that large vortices formed at the back of buildings might produce high suction on the roof. This and other impacts associated with structures with various leakage features, were analysed by Kandola [71] in a paper which contained a discussion on smoke-control challenges. The impact of twodimensional assumptions in computations have been analysed by conducting both 2D and 3D modelling [72]. The modelling was conducted by the Fire Dynamics Simulator software [73-75] which is usually applied to the simulation of fire-generated flow. They proved that FDS is capable of modelling flame spread and specifying the optimum measure for the combustible load substance. In 1992, Than [76] found that wind effects can increase 
smoke extraction as it produces negative pressures in roof ventilators (which are intensively applied in industrial structures to remove smoke, heat, contaminations and odors from the interiors of the structure). Window failure in an apartment fire in the presence of an external wind can lead to rapid and considerable growths in the fire's heat production. Combined with stairs, downward apartments or open doors to corridors, several winddriven fire incidents have led to firefighter's injuries and fatalities [77,78]. Three methods that have attracted great attention in numerous research works are: reducing the flow into an apartment with a window fire curtain or blanket, positive pressure ventilation and suppressing the fire using an external water flow [79]. Positive pressure ventilation is used to remove heat and smoke or prevent heat and smoke from entering the structure's stairwell and public hallways. Positive pressure ventilation is being applied by firefighters in smaller buildings to control fire-driven airflow by exerting pressure from the front door and venting the building via a strategic exit opening [80-82].

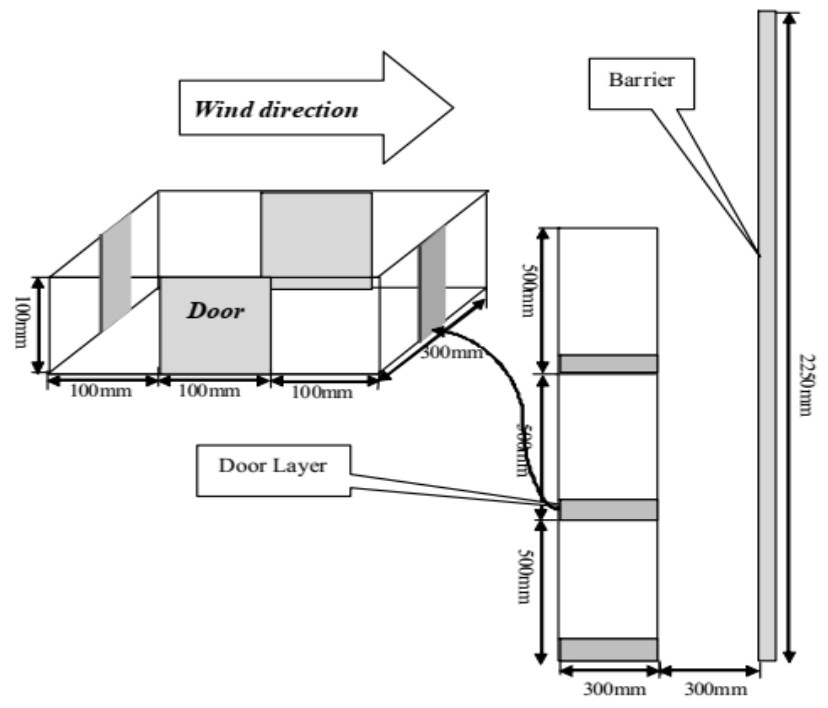

(a)

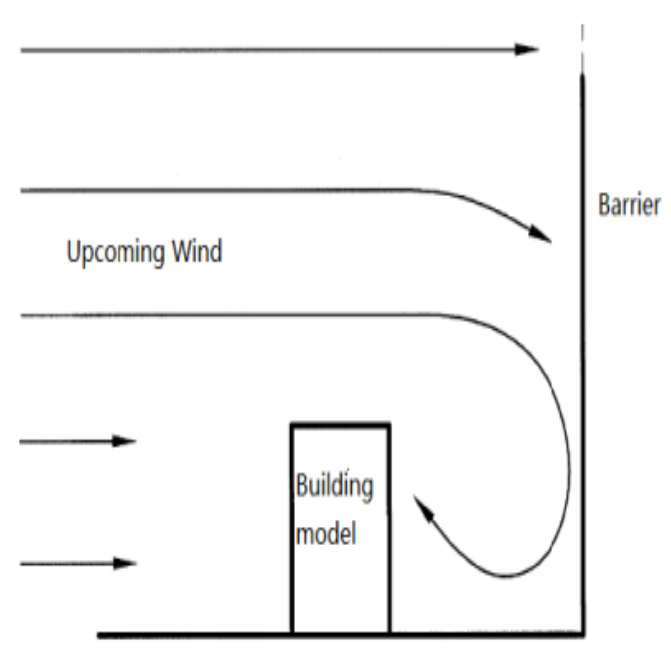

(b)

Figure 6. (a) Experimental equipment. (b) wind flow [60,61].

\subsubsection{Fire-Wind Interaction Effects on High-Rise Buildings}

As wind velocity grows with altitude, so does the possibility of facing wind-driven fires. High-rise structures naturally create unforeseeable, abnormal flows due to this higher altitude. With increasing concentrations of high-rise structures and rising numbers of injuries and fatalities, assessing and improving firefighting methods and developing new firefighting techniques become essential for the safety of today's high-rise structures. Cai and Chow [83] found that it is of great significance to understand the effect of wind on smoke and plume spread and that estimating the spread and initiation of building fires is an essential requirement in today's research practice. These authors conducted a numerical analysis on smoke motion and flame geometry resulting from fire in windy conditions. Their results illustrated that the lateral spread of smoke and flame has a direct relationship with wind speed in the crosswind axis. Smoke will extend laterally under crosswind, potentially spreading to nearby fuel. This is especially significant in high rise structures where higher stack pressure is observed [84] due to high wind speed at the upper levels. Results also showed that the distribution of particles and smoke increases as the wind speed intensifies (as can be seen in Figure 7). 


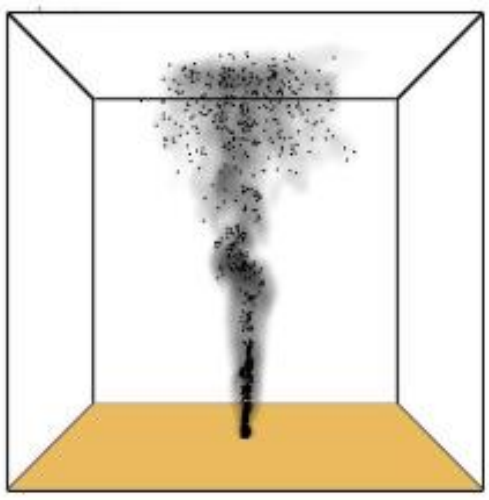

(a)

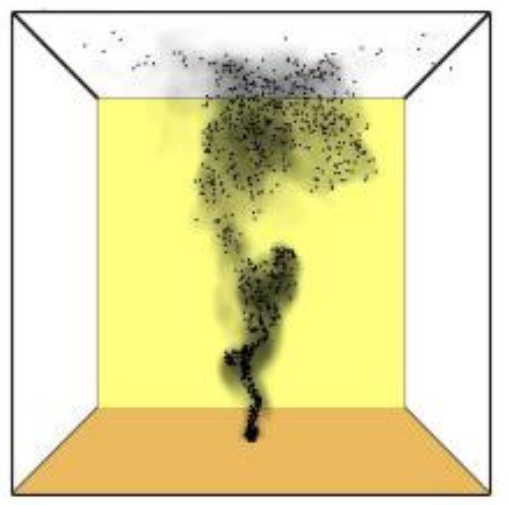

(b)

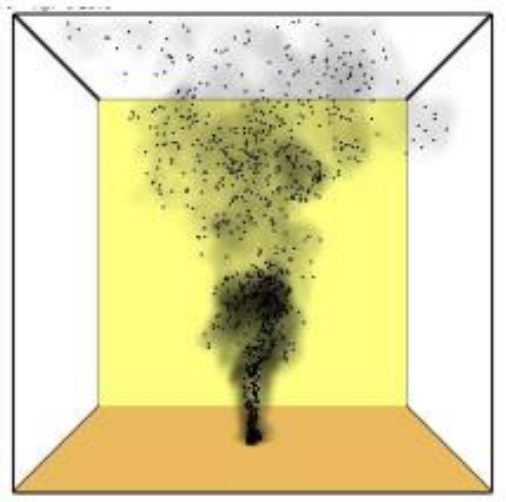

(c)

Figure 7. Smoke distribution in cross-wind direction for different wind speed [83] $((\mathbf{a}) \mathrm{v}=0,(\mathbf{b}) \mathrm{v}=1(\mathrm{~m} / \mathrm{s}),(\mathbf{c}) \mathrm{v}=2.5(\mathrm{~m} / \mathrm{s}))$.

Positive pressure ventilation was applied for high-rise building fires to establish the possibility of using stair pressurisation as an effective tool for safeguarding smokefree conditions in high-rise structures [85-87]. These studies [85-87] proved that positive pressure ventilation fans, when installed correctly and in the right place, can provide higher pressure to areas to control or mitigate the spread of a fire, improving the firefighters' and residents' safety. As the number of injuries and fatalities from wind-driven fires in high rise buildings have escalated, a set of 14 burn tests were conducted which focused on finding the effect of wind conditions and ventilation on high-rise fires and improving techniques to tackle these fires in a safe manner [88]. Panindre et al. [89] highlighted the impact of positive pressure ventilation in decreasing the temperature at locations significant to the safety of firefighters. Their results showed that following activation of positive pressure ventilation fans, the roof door should be closed prior to opening the fire floor stairwell door. Even though positive pressure ventilation decreases the risks of wind-driven fires, its effect can be reduced further with increasing wind velocity. In addition, changing the ventilation of the structures by opening windows or doors can increase the expansion rate of fires and lead to larger spread beyond the original room, resulting in an increase of combustion gases spread in the structure.

A window failure in an apartment fire in the presence of an external wind can lead to fast and considerable growth in heat generation. Combined with stairs, downward buildings and windows, wind-fire interactions can cause major injuries and fatalities for firefighters (Figure 8a). One example of this wind-fire interaction is that the coupled effects of external wind and convection cause hot gasses and smoke to be expelled from the opening, typically traveling vertically upwards. The Coanda effect (the tendency of a flow to stay attached to a nearby surface rather than following a straight line in its original direction) forces these combustion products to be drawn back to the building façade. This is a typical cause of external fire spread (Figure $8 b$ ).

The Fire Research Laboratory of the National Institute of Standards and Technology, working with the fire departments of New York City, Chicago and Polytechnic Institute of New York University, developed a wind control system which when installed in levels above a fire, restricted the effects of wind on the fire. This mechanism is basically a curtain of fire-resistant substance which can be installed over a window or other openings to stop the wind momentum and restrict the oxygen exposure of the fire. In 2007, Polytechnic Institute and NIST started collaborating with the Fire Department of New York to analyse wind-driven fires in high-rise structures. Doing the tests in a laboratory presented the highest levels of control for researchers. 


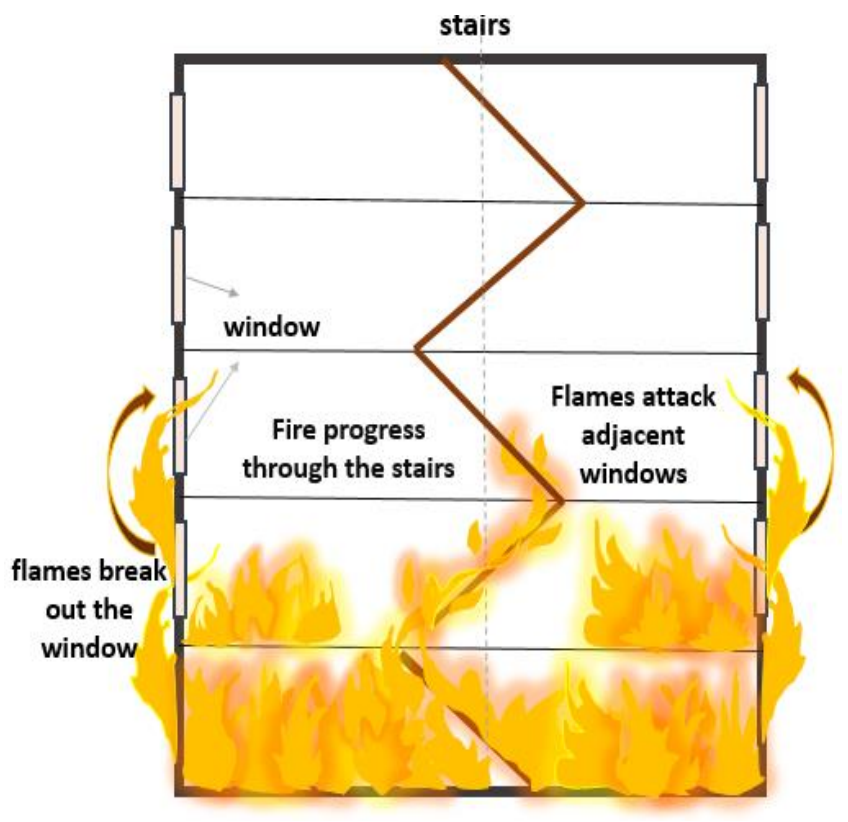

(a)

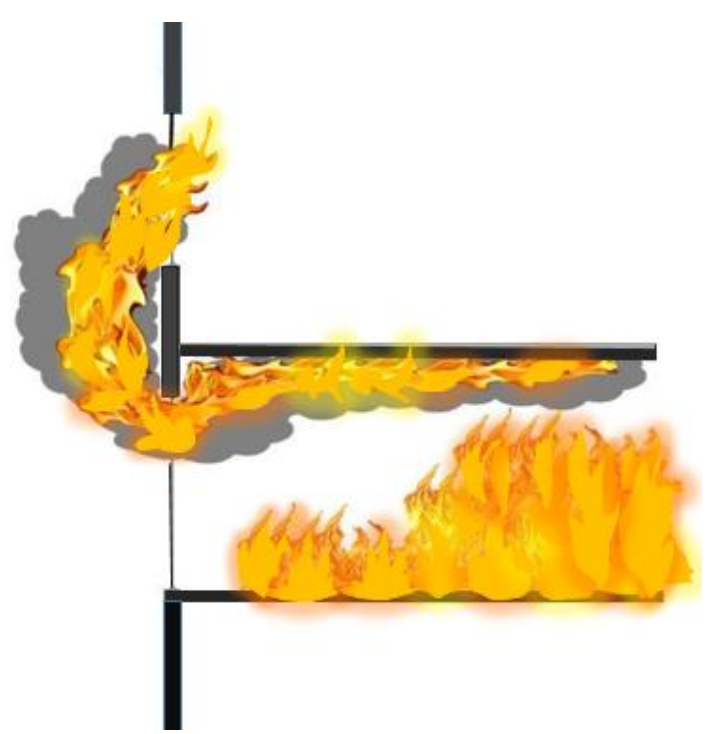

(b)

Figure 8. (a) Mechanism of fire spread in a building by the external windows and stairs, (b) The Coanda effect.

The tests were designed to expose a public corridor region to a wind-driven fire and post-flashover apartment fire. For each of the tests, the door from the building to the corridor was kept open and the fire was ignited in the building's bedroom (Figure 9). The heat of the fire travelled along the hallway towards the end of the building. Before venting or failure of the bedroom window, the rate of thermal energy release from the fire was about 1 MW. Remotely, the trash enclosure was ignited, and the fire grew [84,89].

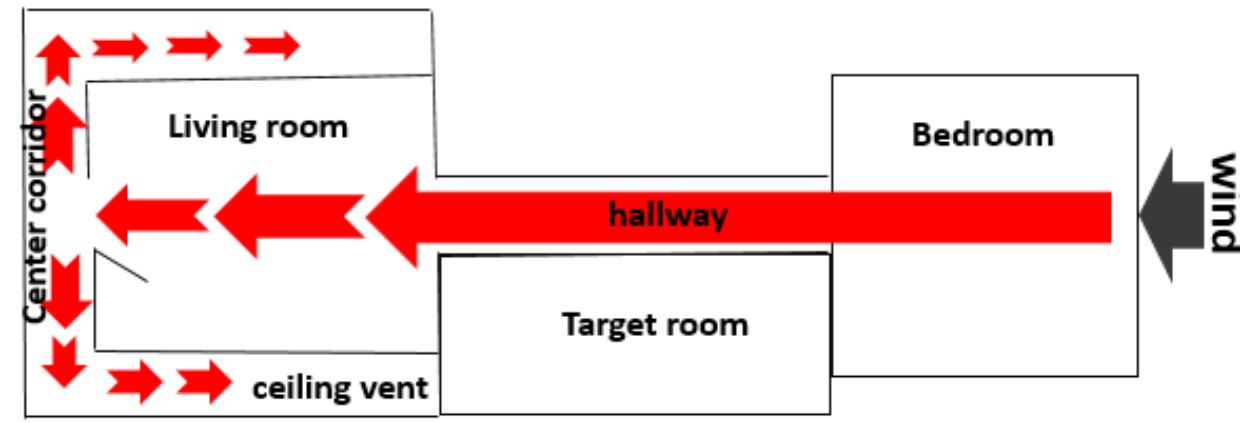

Figure 9. Schematic view of structure in the experimental analysis.

A summary of the conducted tests is presented in Table 1. First, the fire tests in the building were different from the other tests because there was not any external wind acting on the building. The second test was conducted to analyse the effect of wind on the building fire and to quantify the effect of large wind control mechanisms (Figure 10a,b). The other tests were carried out to investigate the effect of wind on the fire, quantify the effect of small wind-control devices (WCD) and finally quantify the effect of a small water spray (about 1.9 Lit/s) into the window (Figure 10c). 
Table 1. The summary of the tests conducted by Kerber and Madrzykowski (2009), [86].

\begin{tabular}{|c|c|c|c|c|c|}
\hline Exp. & Descriptions & $\begin{array}{c}\text { Heat Release } \\
\text { Rate (MW) }\end{array}$ & $\begin{array}{l}\text { Temperature } \\
\text { of Hall } \\
\text { Thermocouple } \\
\text { Array }\left({ }^{\circ} \mathrm{C}\right)\end{array}$ & $\begin{array}{l}\text { Max Heat Flux } \\
\quad\left(\mathrm{kW} / \mathrm{m}^{2}\right)\end{array}$ & $\begin{array}{l}\mathrm{CO}_{2}(\% \text { Volume }) \\
\text { from the Lower } \\
\text { Living Room } \\
\text { Sampling Location }\end{array}$ \\
\hline 1 & $\begin{array}{l}\text { There is not any external wind to the } \\
\text { building. Once the fire within the } \\
\text { building was identified to be fully } \\
\text { improved, the fire was suppressed by } \\
\text { safety sprinklers located in the } \\
\text { building. The outcomes are associated } \\
\text { with the time interval of begin } \\
\text { suppression and window venting. }\end{array}$ & $1.5-14$ & $300-1200$ & $30-90$ & 5-18 \\
\hline 2 & $\begin{array}{l}2 \text { WCD were applied (the outcomes are } \\
\text { associated with the time interval of } \\
\text { WCD off and WCD on) }\end{array}$ & $15-2$ & $800-350$ & 100-20 & $16-11$ \\
\hline 3 & $\begin{array}{l}2 \text { WCD and a tiny water spray were } \\
\text { applied (the outcomes are associated } \\
\text { with the time interval of Sprinkler on } \\
\text { and WCD on) }\end{array}$ & $20-1.5$ & $800-300$ & $140-50$ & $17-6$ \\
\hline
\end{tabular}

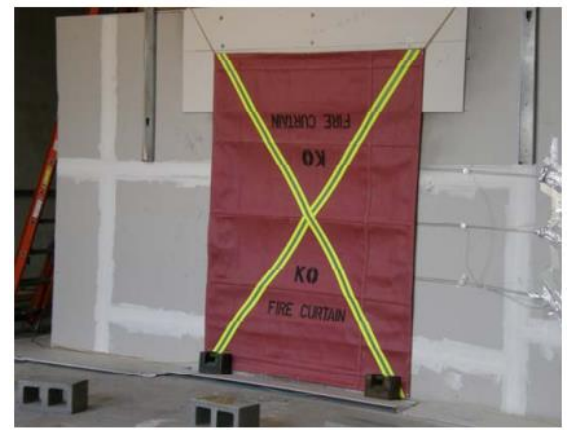

(a)

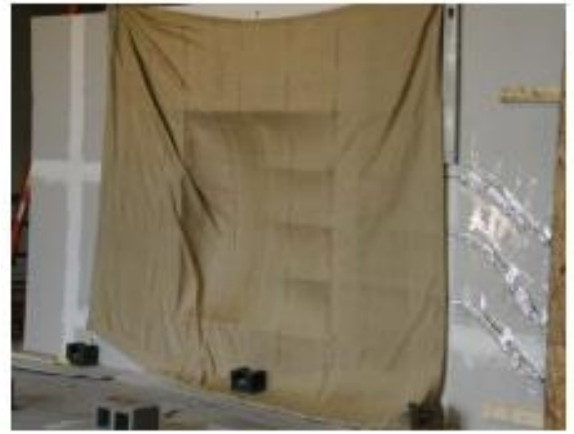

(b)

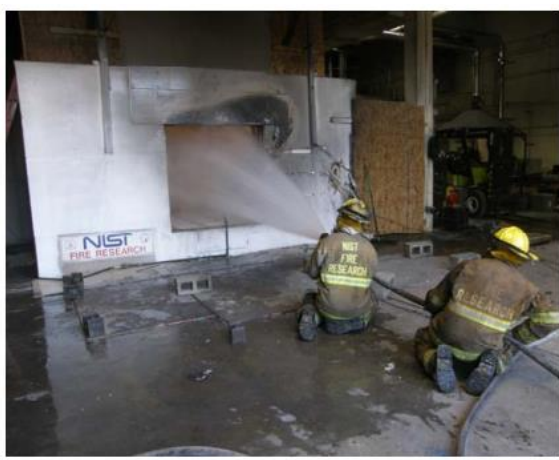

(c)

Figure 10. Installation of wind-control devices (WCD). (a) Small WCD located in window, (b) Large WCD located in window, (c) Water spray into window.

These tests showed that wind control systems were efficient in decreasing the thermal risks in the corridor. By modelling different fire scenarios with the use of available software, including NIST's Fire Dynamic Simulator and Fluent 6.3, the capability of positive pressure ventilation to reduce heat and smoke, and therefore increase the safety and visibility of firefighters in rescue operations, were shown. The study also showed that using a wind control system in high-rise building fires decreases the wind-driven impact on a fire and 
strengthens the efficiency of positive pressure ventilation (even in the existence of stronger winds) [86,91].

As the timelines of the tests (for instance, WCD off WCD on, window vented and ignition) are distinct for each test, the outcomes of the tests are substantially different in range. In test 1 , following venting the window, the rate of thermal release increased from about 1.5 MW to about 14 MW. In test 2, using WCD led to a drop in the rate of thermal release. The temperature was reduced because of the cooling effect of wind which blows air into the opening. In test 3 , at the period that the window sprinkler was turned on, the rate of thermal release was decreased to about 1.5 MW. Overall, according to [86], the WCDs decreased the temperatures by over 50 percent. The thermal fluxes decreased nearly 70 percent. In addition, Madrzykowski [86] asserted that more study in an actual structure is needed to fully understand the capability of firefighters to perform these methods and to analyse the thermal conductions in the building. Therefore, wind-control systems implementation is suggested to maintain acceptable conditions for firefighters.

Other outcomes from Madrzykowski's test [86] are presented as below:

- In all structural tests, the WCDs decreased the temperatures in the stairwell and the corridor.

- The streams of water suppressed the fires, leading to decreases of over $50 \%$ in the stairwell and corridor temperature.

- When positive pressure ventilation fans are used along with WCDs, fans can maintain clear and reasonable conditions in the stairwell. The main reason for the successful usage of positive pressure ventilation fans was to reduce the wind-driven fire conditions through door control or other techniques.

According to Panindre and his co-authors [90], using WCDs with parallel installation of positive pressure ventilation can escalate the levels of pressure obtained by positive pressure ventilation operations to reduce the heat flow and drop the temperatures in public hallways and stairwells. This will remarkably increase the performance of positive pressure ventilation operation.

\section{Conclusions and Future Challenges}

In many cases the combination of wind and fire can create hugely destructive forest fires, which are often close to urban regions and can result in building fires. Most such phenomena are affected by wind, which causes more severe conditions. To better understand the fire behaviour and characteristics, it is essential to understand the wind features and simulate the forced convection produced by wind properly. The key aim of this review article was to present a summary of existing advances in numerical and experimental investigations of wind-fire interaction phenomena and their impacts on structures. The main findings in the context of fire wind interaction effects can be summarised as follows:

- The behaviours of airflow are of primary importance in determining fire progression on the rate of thermal release associated with buildings.

- At a WUI, both structural and wildland fuels are combined. Simulations of this regime must consider the coupling effects between structural and wildland fuels.

- Ventilation operation mitigates the hazards of wind-driven fires. The effectiveness of this operation was found to decline with increasing wind speed.

- Using wind-control devices (WCDs) is suggested to maintain safe conditions for firefighters. In all tests, the use of WCDs decreased observed temperatures.

- As positive pressure ventilation is applied along with WCDs, fans are able to maintain acceptable conditions (as the fan was turned on, it takes time for the fire to obtain its rate of peak burning, and the stream of gases was forced away from the entrance).

- Using sprinklers dramatically reduces the thermal fluxes and temperature. 


\section{Future Directions}

- An accurate analysis of fire behaviour in compartments of low and high-rise structures in wind environments are required to find efficient methods to assess compartment fire smoke control and travel.

- The other side of the coupled interaction of wind and fire is the enhancement of the wind downstream of a fire source. Investigation of the impact of fire on wind is not adequately conducted and needs further exploration.

- Although there are some studies on wildland-urban interface fires, little effort has been allocated to serious analysis of the physical aspects of wildland-urban interface fire propagation. In addition, it is hoped that further simulation endeavours might produce better cooperation and communication between fire safety specialists and WUI scientists.

- More research around real size structures is needed to fully comprehend the capability of firefighters to work with the proposed tactics, and to assess the interaction of these tactics with structure ventilation methods (both natural and positive pressure ventilation).

- Further investigation is required to analyse the critical wind velocity at the stairways and doorways of high-rise buildings.

- Improvement of new techniques for smoke exhaust devices including exact impact of external aerodynamic elements on smoke ventilators (considering a wide range of wind speeds and angles) is needed.

Author Contributions: Methodology, M.G. and A.S.; formal analysis, F.S. and M.G.; writingoriginal draft preparation, M.G. and F.S.; writing-review and editing, M.G., A.S. and D.J.N.; visualisation, A.S., M.G., F.S. and D.J.N.; supervision, M.G. and A.S. All authors have read and agreed to the published version of the manuscript.

Funding: This research received no external funding.

Informed Consent Statement: Not applicable.

Data Availability Statement: The data presented in this study are available on request from the corresponding author.

Acknowledgments: The authors thank Sutherland, D. (School of Science, UNSW Canberra) for useful feedback during the preparation of the manuscript.

Conflicts of Interest: The authors declare no conflict of interest.

\section{References}

1. Fire and Rescue NSW. Annual Report; Fire and Rescue NSW: Sydney, Australia, 2019.

2. Haynes, K.; Handmer, J.; McAneney, J.; Tibbits, A.; Coates, L. Australian bushfire fatalities 1900-2008: Exploring trends in relation to the 'Prepare, stay and defend or leave early' policy. Environ. Sci. Policy 2010, 13, 185-194. [CrossRef]

3. Guardian, T. Unprecedented' Globally: More than 20\% of Australia's Forests Burnt in Bushfires. Available online: https: / / www.theguardian.com/australia-news/2020/feb/25/unprecedented-globally-more-than-20-of-australias-forestsburnt-in-bushfires\#maincontent (accessed on 24 February 2020).

4. Mail, B.D. It was A Line of Fire Coming at Us: South West Firefighters Return Home. Available online: https:/ / www.busseltonmail. com.au/story/6620313/it-was-a-line-of-fire-coming-at-us-firefighters-return-home/ (accessed on 7 February 2020).

5. Siness, C. Australia is Promising $\$ 2$ Billion for the Fires. I Estimate Recovery Will Cost $\$ 100$ Billion. Available online: https: / / edition.cnn.com/2020/01/10/perspectives/australia-fires-cost/index.html (accessed on 10 January 2020).

6. $\mathrm{Hu}, \mathrm{L} . ; \mathrm{Wu}, \mathrm{L} . ; \mathrm{Liu}, \mathrm{S}$. Flame length elongation behavior of medium hydrocarbon pool fires in cross air flow. Fuel 2013, 111, 613-620. [CrossRef]

7. Hu, L.; Liu, S.; Xu, Y.; Li, D. A wind tunnel experimental study on burning rate enhancement behavior of gasoline pool fires by cross air flow. Combust. Flame 2011, 158, 586-591. [CrossRef]

8. Li, M.; Gao, Z.; Ji, J.; Li, K.; Sun, J. Wind effects on flame projection probability from a compartment with opposing openings. Fire Saf. J. 2017, 91, 414-421. [CrossRef]

9. Eftekharian, E.; Ghodrat, M.; Ong, R.H.; He, Y.; Kwok, K.C.S. CFD Investigation of Cross-Flow Effects on Fire-Wind Enhancement. In Proceedings of the 21st Australasian Fluid Mechanics Conference, Adelaide, Australia, 10-13 December 2018.

10. Welker, J.R.; Sliepcevich, C.M. Bending of wind-blown flames from liquid pools. Fire Technol. 1966, 2, 127-135. [CrossRef] 
11. Tang, W.; Miller, C.H.; Gollner, M.J. Local flame attachment and heat fluxes in wind-driven line fires. Proc. Combust. Inst. 2017, 36, 3253-3261. [CrossRef]

12. Welker, J.R.; Sliepcevich, C.M. Burning rates and heat transfer from wind-blown flames. Fire Technol. 1966, 2, 211-218. [CrossRef]

13. Woods, J.; Fleck, B.; Kostiuk, L. Effects of transverse air flow on burning rates of rectangular methanol pool fires. Combust. Flame 2006, 146, 379-390. [CrossRef]

14. Hu, L.; Kuang, C.; Zhong, X.; Ren, F.; Zhang, X.; Ding, H. An experimental study on burning rate and flame tilt of optical-thin heptane pool fires in cross flows. Proc. Combust. Inst. 2017, 36, 3089-3096. [CrossRef]

15. Ghaderi, M.; Ghodrat, M.; Sharples, J. LES Simulation of Wind-Driven Wildfire Interaction with Idealized Structures in the Wildland-Urban Interface. Atmosphere 2020, 12, 21. [CrossRef]

16. Oka, Y.; Kurioka, H.; Satoh, H.; Sugawa, O. Modelling of Unconfined Flame Tilt In Cross-Winds. Fire Saf. Sci. 2000, 6, 1101-1112. [CrossRef]

17. Weise, D.R.; Biging, G.S. Effects of wind velocity and slope on flame properties. Can. J. For. Res. 1996, 26, 1849-1858. [CrossRef]

18. Nelson, R.M. An effective wind speed for models of fire spread. Int. J. Wildland Fire 2002, 11, 153-161. [CrossRef]

19. Zhou, K.; Liu, N.; Yin, P.; Yuan, X.; Jiang, J. Fire Whirl due to Interaction between Line Fire and Cross Wind. Fire Saf. Sci. 2014, 11, 1420-1429. [CrossRef]

20. Yoshihara, N.; Ito, A.; Torikai, H. Flame characteristics of small-scale pool fires under low gravity environments. Proc. Combust. Inst. 2013, 34, 2599-2606. [CrossRef]

21. $\mathrm{Hu}, \mathrm{L}$. A review of physics and correlations of pool fire behaviour in wind and future challenges. Fire Saf. J. 2017, 91, 41-55. [CrossRef]

22. Fang, J.B. An Investigation of the Effect of Controlled Wind on the Rate of Fire Spread. Ph.D. Thesis, University of New Brunswick, Fredericton, NB, Canada, 1969.

23. Sheshukov, M.A. Effect of the steepness of the slope on the propagation rate of fire. Lesn. Khozyaystvo 1970, 1, 50-54.

24. Van Wagner, C.E. Effect of slope on fire spread rate. Can. For. Serv. Bimon. Res. Notes 1970, 33, 1-2.

25. Weise, D.R.; Biging, G.S. Effects of Wind Velocity and Slope on Fire Behavior. In Proceedings of the Fourth International Symposium on Fire Safety Science, Boston, MA, USA, 13-17 June 1994.

26. Linn, R.; Winterkamp, J.; Edminster, C.; Colman, J.J.; Smith, W.S. Coupled influences of topography and wind on wildland fire behaviour. Int. J. Wildland Fire 2007, 16, 183-195. [CrossRef]

27. Sharples, J.J. Review of formal methodologies for wind-slope correction of wildfire rate of spread. Int. J. Wildland Fire 2008, 17, 179-193. [CrossRef]

28. Weise, D.R.; Biging, G.S. A qualitative comparison of fire spread models incorporating wind and slope effects. For. Sci. 1997, $43,170-180$.

29. Sharples, J.J.; McRae, R.H.D.; Weber, R.O. Wind characteristics over complex terrain with implications for bushfire risk management. Environ. Model. Softw. 2010, 25, 1099-1120. [CrossRef]

30. Sharples, J.J.; Viegas, D.X.; Rossa, C.G.; Mcrae, R.H.D. Small-Scale Observations of Atypical Fire Spread Caused by the Interaction of Wind, Terrain, and Fire. In Proceedings of the VI International Conference on Forest Fire Research D, 15-18 November 2010, Coimbra, Portugal; Viegas, D.X., Ed.; ADAI: Coimbra, Portugal, 2010; p. 363.

31. Zheng, L.; Zhou, L.; Jia, X.; Li, X. Influence of Wind Direction on Fire Spread on the Exposed XPS insulation Wall. IOP Conf. Series Earth Environ. Sci. 2020, 526, 1-5.

32. Quill, R.; Sharples, J.J.; Wagenbrenner, N.S.; Sidhu, L.A.; Forthofer, J.M. Modeling Wind Direction Distributions Using a Diagnostic Model in the Context of Probabilistic Fire Spread Prediction. Front. Mech. Eng. 2019, 5, 1-16. [CrossRef]

33. Węgrzyński, W.; Lipecki, T.; Krajewski, G. Wind and Fire Coupled Modelling-Part II: Good Practice Guidelines. Fire Technol. 2018, 54, 1443-1485. [CrossRef]

34. Wieringa, J. Updating the Davenport roughness classification. J. Wind. Eng. Ind. Aerodyn. 1992, 41, 357-368. [CrossRef]

35. Mell, W.E.; Manzello, S.L.; Maranghides, A.; Butry, D.; Rehm, R.G. The wildland-urban interface fire problem-current approaches and research needs. Int. J. Wildland Fire 2010, 19, 238-251. [CrossRef]

36. Rehm, R.G.; Mell, W. (Ruddy) A simple model for wind effects of burning structures and topography on wildland-urban interface surface-fire propagation. Int. J. Wildland Fire 2009, 18, 290-301. [CrossRef]

37. Murphy, K.; Rich, T.; Sexton, T. An Assessment of Fuel Treatment Effects on Fire Behavior, Suppression Effectiveness, Structure Ignition on the Angora Fire. In USDA Forest Service, Pacific Southwest Research Station, Report R5-TP-025; United State Department of Agriculture: Vallejo, CA, USA, 2007.

38. Rehm, R.G. The effects of winds from burning structures on ground-fire propagation at the wildland-urban interface. Combust. Theory Model. 2008, 12, 477-496. [CrossRef]

39. Mahmoud, H.; Chulahwat, A. Unraveling the Complexity of Wildland Urban Interface Fires. Sci. Rep. 2018, 8, 1-12. [CrossRef]

40. Maluk, C.; Woodrowc, M.; Toreroa, J.L. The potential of integrating fire safety in modern building design. Fire Saf. J. 2017, 88, 104-112. [CrossRef]

41. Zou, Y.; Kiviniemi, A.; Jones, S.W. A review of risk management through BIM and BIM-related technologies. Saf. Sci. 2017, 97, 88-98. [CrossRef]

42. Cao, S.; Song, W.; Lv, W. Modeling pedestrian evacuation with guiders based on a multi-grid model. Phys. Lett. A 2016, 380, 540-547. [CrossRef] 
43. Tanachawengsakul, T.; Mishima, N.; Fuchikami, T. A Simulation Study on Fire Evacuation Routes in Primary Stage for a Historic Canal Residential Area. Procedia Soc. Behav. Sci. 2016, 216, 492-502. [CrossRef]

44. Mikkola, E. Forest fire impacts on buildings. For. Fires 2008 2008, 119, 237-243. [CrossRef]

45. Noble, I.R.; Bary, G.A.V.; Gill, A.M. McArthur's fire-danger meters expressed as equations. Aust. J. Ecol. 1980, 5, $201-203$. [CrossRef]

46. Cunningham, P.; Goodrick, S.L.; Hussaini, M.Y.; Linn, R.R. Coherent vortical structures in numerical simulations of buoyant plumes from wildland fires. Int. J. Wildland Fire 2005, 14, 61-75. [CrossRef]

47. Coen, J.L. Simulation of the Big Elk Fire using coupled atmosphere-fire modeling. Int. J. Wildland Fire 2005, 14, 49-59. [CrossRef]

48. Ramsay, G.C.; McArthur, N.A.; Dowling, V.P. Preliminary results from an examination of house survival in the 16 February 1983 Bushfires in Australia. Fire Mater. 1987, 11, 49-51. [CrossRef]

49. Baalisampang, T.; Abbassi, R.; Garaniya, V.; Khan, F.; Dadashzadeh, M. Fire impact assessment in FLNG processing facilities using Computational Fluid Dynamics (CFD). Fire Saf. J. 2017, 92, 42-52. [CrossRef]

50. McGrattan, K.; Klein, B.; Hostikka, S.; Floy, J. Fire Dynamics Simulator (Version 5)-User's Guide. NIST Spec. Publ. 2009, 1019, 1-186.

51. McGrattan, K.; Hostikka, S.; Floy, J.; Baum, H.; Rehm, R.; Mell, W.; McDermott, M. Fire Dynamic Simulator (Version 5) Technical Reference Guide. NIST Spec. Publ. 2008, 1008, 1-86.

52. He, Y.; Kwok, K.C.S.; Douglas, G.; Razali, I.M. Numerical Investigation of Bushfire-Wind Interaction and its Impact on Build-ing Structure. Fire Saf. Sci. 2011, 10, 1449-1462. [CrossRef]

53. Kramer, C.; Gerhardt, H.J. Windkrfifte auf Flachen und Wenig Geneigten Dachflfichen. In Proceedings of the Dokumenta-tion zum 2. Kolloquium uber Industriaerodynamik, Aachen, Germany, 12-13 December 1976.

54. Kramer, C.; Gerhardt, H.J. Wind pressures on roofs of very low and very large industrial buildings. J. Wind Eng. Ind. Aerodyn. 1991, 38, 285-295. [CrossRef]

55. Kramer, C.; Gerhardt, H.J. Wind effects on heat and smoke control of industrial buildings in case of a fire. J. Wind Eng. Ind. Aerodyn. 1990, 36, 499-508. [CrossRef]

56. Johansson, N.; Ekholm, M. Variation in Results Due to User Effects in a Simulation with FDS. Fire Technol. 2017, 54, 97-116. [CrossRef]

57. Available online: https:/ / www.highrisefirefighting.co.uk/wind.html (accessed on 28 February 2020).

58. ABCB. Building Code of Australia; Australian Building Codes Board: Canberra, Australia, 2010.

59. Onga, R.H.; Patrunob, L.; Yeod, D.; Hee, Y.; Kwok, K.C.S. Numerical simulation of wind-induced mean and peak pressures around a low-rise structure. Eng. Struct. 2020, 214, 110583. [CrossRef]

60. Zhang, C.F.; Chen, S.Y.; Chow, W.K. Wind Effects on the Smoke Spread of High-Rise Buildings. In Proceedings of the 2014 World Congress on Advances in Civil, Environmental, and Material Research (ACEM14), Busan, Korea, $24-28$ August 2014.

61. Šulc, S.; Šmilauer, V.; Wald, F. Coupled Simulation for Fire-Exposed Structures using CFD and Thermo-Mechanical Models. Acta Polytech. CTU Proc. 2017, 13, 121-124. [CrossRef]

62. Šulc, S.; Šmilauer, V.; Patzák, B.; Cábová, K.; Wald, F. Linked simulation for fire-exposed elements using CFD and ther-momechanical models. Adv. Eng. Softw. 2019, 131, 12-22. [CrossRef]

63. Best practice guideline for the CFD simulation of flows in the urban environment. In Pitts WM (1991) Wind effects on fires; Franke, J. (Ed.) COST Office Brussels 5: Bruxelles, Belgium, 2017; Volume 17, pp. 83-134.

64. Barsim, M.M.; Bassily, M.A.; El-Batsh, H.M.; Sherif, M.M. Numerical simulation of an experimental atrium fires in com-bined natural and forced ventilation by CFD. Int. J. Vent. 2020, 19, 1-24.

65. Assunta, A.; Nicola, B.; Marilena, M.; Giuseppe, R. Parametric analysis of input data on the CFD fire simulation. J. Phys. Conf. Ser. 2018, 1224, 012011. [CrossRef]

66. Dana, X.; Wen-lei, Z. The Effect of Natural Wind to the Atrium Building Smoke Migration. Phys. Eng. 2011, 11, 560-565. [CrossRef]

67. Madrzykowski, D.; Walton, W.D. Cook County Administration Building Fire, In 69 West Washington, Chicago, Illinois, 17 October 2003: Heat Release Rate Experiments and FDS Simulations; National Institute of Standards and Technology: Gaithersburg, MD, USA, 2004.

68. Huang, Y.; Zhou, X.; Cao, B.; Yang, L. Effects of ventilation state of vertical shaft on fire tilt direction and smoke migration behaviours in a multi-storey building. Indoor Built Environ. 2018, 18, 790-805. [CrossRef]

69. Kandola, B.S. Effects of atmospheric wind on flows through natural convection roof vents. Fire Technol. 1990, 26, 106-120. [CrossRef]

70. Marchant, E.W. Effect of wind on smoke movement and smoke control systems. Fire Saf. 1984, 7, 55-63. [CrossRef]

71. Kandola, B.S. Wind effects on buildings with varying leakage characteristics—wind-tunnel investigation. J. Wind Eng. Ind. Aerodyn. 1978, 3, 267-284. [CrossRef]

72. Hostikka, S.; Mangs, J.; Mikkola, E. Comparison of Two and Three Dimensional Simulations of Fires at Wildland Urban Inter-face. In Proceedings of the 9th IAFSS Symposium, Karlsruhe, Germany, 21-26 September 2008.

73. McDermott, R.; McGrattan, K.; Hostikkal, S. Fire Dynamics Simulator (Version 5): Technical Reference Guide. NIST SP 1018-5. NIST Spec. Publ. 2007, 1018, 1-186.

74. Akovchuk, R.Y.; Kuzyk, A.; Skorobagatko, T.; Yemelyanenko, S.; Borys, O.; Obrostan, O. Computer simulation of fire test parameters facad heat insulating system for spread in fire spread in fire dynamics simulator (FDS). Ser. Geol. Tech. Sci. 2020, 4, 35-44. 
75. Mirahadi, F.; Mc Cabe, B.; Shahi, A. IFC-centric performance-based evaluation of building evacuations using fire dynamics simulation and agent-based modeling. Autom. Constr. 2019, 101,1-16. [CrossRef]

76. Than, C.F. Smoke venting by gravity roof ventilators under windy conditions. J. Fire Prot. Eng. 1992, 4, 1-4. [CrossRef]

77. Pettit, T.A.; Washenitz, F.; Cortez, K. Three Firefighters Die in a 10-Story High-Rise Apartment Building-New York. NIOSH Firefighter Fatality Investigation and Prevention Program: Morgantown, WV, USA, 1999.

78. NIOSH F2001-33. High-Rise Apartment Fire Claims the Life of One Career Firefighter (Captain) and Injures Another Career Firefighter (Captain)-Texas; NIOSH Firefighter Fatality Investigation and Prevention Program: Morgantown, WV, USA, 2002.

79. John, N. Extreme Wind Driven Fireproof Multiple Dwelling Fires; With New York Firefighters (WNYF): New York, NY, USA, 2007.

80. Kerber, S. Evaluation of the Ability of Fire Dynamic Simulator to Simulate Positive Pressure Ventilation in the Laboratory and Practical Scenarios; National Institute of Standards and Technology: Gaithersburg, MD, USA, 2006.

81. Kerber, S.; Walton, W.D. Full Scale Evaluation of Positive Pressure Ventilation in a Firefighter Training Building; National Institute of Standards and Technology: Gaithersburg, MD, USA, 2006.

82. Kerber, S.; Madrzykowski, D.; Stroup, D. Evaluating Positive Pressure Ventilation in Large Structures: High-Rise Pressure Experiments; National Institute of Standards and Technology: Gaithersburg, MD, USA, 2017.

83. Cai, N.; Chow, W.K. Wind Effect on Spread of Fire and Smoke. In Proceedings of the 2012 World Congress on Advances in Civil, Environmental, and Materials Research (ACEM' 12), Seoul, Korea, 26-30 August 2021.

84. Jo, J.; Lim, J.; Song, S.; Yeo, M.; Kim, K. Characteristics of pressure distribution and solution to the problems caused by stack effect in high-rise residential buildings. Build. Environ. 2007, 42, 263-277. [CrossRef]

85. Madrzykowski, D.; Kerber, S.; Kumar, S.; Panindre, P. Wind, fire and high-rises: Firefighters and engineers conduct research to combat a lethal threat. Mag. Am. Soc. Mech. Eng. 2010, 132, 22-27.

86. Lambert, B.; Merci, K. Experimental study on the use of positive pressure ventilation for fire service interventions in buildings with staircases. Fire Technol. 2014, 50, 1517-1534. [CrossRef]

87. Wener, R.; Panindre, P.; Kumar, S.; Feygina, I.; Smith, E.; Dalton, J.; Seal, U. Assessment of web-based interactive game system methodology for dissemination and diffusion to improve firefighter safety and wellness. Fire Saf. J. 2015, 72, 59-67. [CrossRef]

88. Kerber, S.I.; Madrzykowski, D. Fire Fighting Tactics under Wind Driven Fire Conditions: 7-Story Building Experiments. In NIST Technical Note 1629; Building and Fire Research Laboratory: Gaithersburg, MD, USA, 2009.

89. Panindre, P.; Mousavi, S.; Kumar, S. Positive Pressure Ventilation for fighting wind-driven high-rise fires: Simulation-based analysis and optimization. Fire Saf. J. 2017, 87, 57-64. [CrossRef]

90. F99-01, NIOSH. Three Firefighters Die in a 10-Story High-Rise Apartment Building-New York. NIOSH Firefighter Fatality Investigation and Prevention Program: Morgantown, WV, USA, 1999. Available online: http://www.cdc.gov/niosh/fire/ reports / face9901.html (accessed on 8 January 2020).

91. Hall, J., Jr. High-Rise Building Fires; National Fire Protection Association: Quincy, MA, USA, 2013. 